\title{
Land Degradation, Community Perceptions and Environmental Management Implications in the Drylands of Central Tanzania
}

\author{
Richard Y.M. Kangalawe
}

Additional information is available at the end of the chapter

http://dx.doi.org/10.5772/45897

\section{Introduction}

Land degradation particularly through soil erosion is an important concern in many parts of the world including semiarid areas of central Tanzania. One of the issues that have gained importance is the concern on implications of local perceptions in resource management. The Irangi Hills (Figure 1) are severely affected by soil degradation; hence they provide a vivid example for studying environmental degradation, local perceptions, and land-management strategies that the local population use to cope with the degradation problems [1]. The Irangi Hills have been influenced by various land management interventions, for example, the implementation of various soil-conservation measures that have contributed to considerable changes in the spatial and temporal land-use patterns during the 20th century, and particularly over the last four decades. The Irangi Hills, located in Kondoa District in semiarid, central Tanzania (Figure 1), constitute about 10\% (c. $1256 \mathrm{~km}^{2}$ ) of the District area that has been particularly affected by sheet and gully soil erosion $[2,3,4,5,6,7]$. In many places soil erosion has reduced the agricultural potential of the land by the physical removal of topsoil, sand deposition on lower slopes and valley floors, and gullying and incipient badlands development [7]. The sub-humid, north-eastern parts of the Irangi Hills are more severely degraded than the semiarid south and south-west.

A combination of factors makes soil erosion a particularly serious problem in these semiarid areas of Tanzania. The problem has often been associated with local mismanagement of the land resources through among others, overgrazing, over-cultivation, burning of grasslands and woodlands, resulting in over-exploitation and consequent soil erosion [8]. However, it has been shown in recent studies in the Irangi Hills that the problems and causes may be more complex than was earlier presumed, including factors such as tectonic activities and historical changes in climatic conditions $[9,10,11,12]$. 
In southern Africa, where many researchers are engaged in land management and conservation issues, many have included the aspect of perception and their influence on resource management by various groups of the society $[13,14,15]$. Local perceptions can be established by interviewing local people about how they viewed various resource conditions [16]. The importance of acknowledging the socio-economic environment of the various decision making groups involved is discussed in [17]. Also Dahlberg [18] accorded considerable importance on local views in the study of environmental change and degradation in Botswana. Understanding the local people's perceptions on environmental issues is thus a prerequisite in making successful and sustainable resource management strategies.

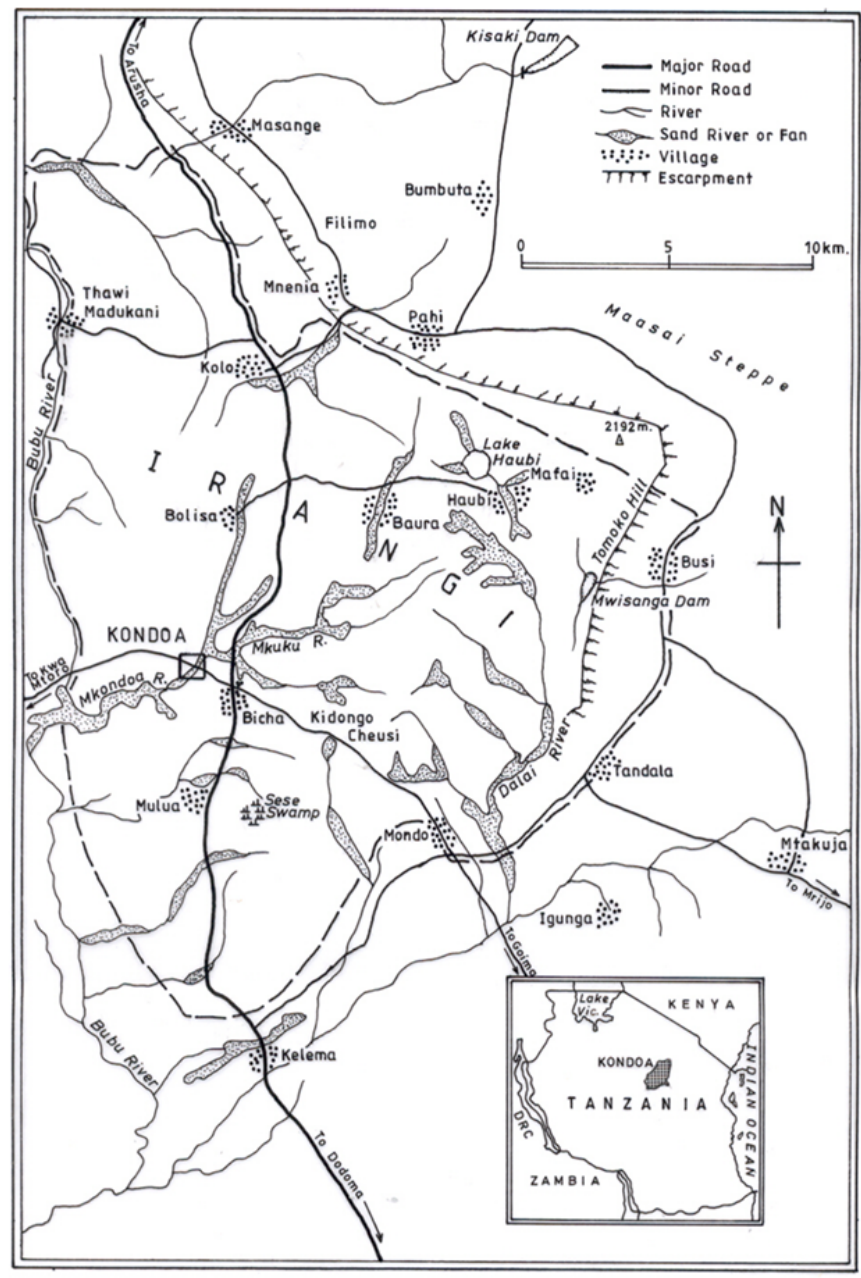

Figure 1. Map of the Irangi Hills showing the Kondoa Eroded Area and the surveyed villages of Mafai, Baura and Bolisa. The insert is a map of Tanzania showing the location of Kondoa. 
Local people's perceptions of environmental issues can be looked at from three perspectives. First, people will perceive land degradation on the basis of their socioeconomic interests. In this case, farmers will be more aware and concerned about environmental changes and damages that affect agricultural productivity such as soil erosion. Secondly, when these people understand that their physical environment is deteriorating they will attempt to control some of their activities leading to degradation [19], thereby be more willing to support land management programmes if they are aware that their actions are harmful to the environment [20]. Various social, economic, technological and ecological often exist, changing degrading practices especially where communities are aware of the negative impacts of current land management practices. Communities in the Irangi Hills have demonstrated their willingness to participate in conservation initiatives as indicated by their adoption of various conservation measures reported later in the chapter.

The third perspective from attitude survey shows that a large majority of farmers are concerned about soil and/or land degradation as a general community problem, disregarding the fact that their own holdings are likely to be also at risk [21]. Under such circumstances then no actions may be taken although such people hold positive attitudes towards conservation. However, it is believed that when the landowners themselves have been involved in fact-finding on their own land they become instrumental in implementing planned courses of action [22]. Thus basing on the local people's perceptions of environmental resources and knowledge then it is possible to develop methods which can allow the people themselves to provide the solutions to their environmental problems [19, $22,23]$. Generally, planning for and implementation of effective soil and water conservation measures in a site require, among other things, a detailed understanding of the extent, risk and spatial distribution of the problem [24, 25], including local concerns.

While sustainable management of resources leads to sustainable development, the deeprooted poverty leads to overdependence on natural resources for livelihood which in some instances has undermined the capacity of the communities to manage their resources sustainably. This problem is more critical in developing countries where rapid population growth leads to the invasion of marginal lands and unsustainable land use practices that in turn encourage environmental degradation and perpetuate poverty.

This chapter is based on a study undertaken in the Irangi Hills to examine the farming community perceptions and awareness on environmental degradation. The main objective was to examine on methods used in the area to improve agricultural productivity and control soil degradation. The specific objectives were: to assess farmers' awareness on soil degradation and conservation, and to study the farming system and resource use in the area. It also examined the mechanisms that are taken by the local communities to address land resource management issues, including approaches used in soil conservation and how such approaches help to improve agricultural productivity and local livelihoods in general. It further examined the factors limiting effective community involvement in land/soil conservation initiatives. 


\section{The study area}

The Irangi Hills (Figure 1) are located in the severely eroded area of Kondoa District known as the Kondoa Eroded Area (KEA). Kondoa District is located in the northern part of

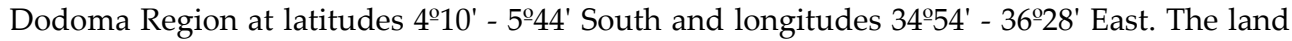
area of the Kondoa District is approximately $13,210 \mathrm{~km}^{2}$, out of which the Kondoa Eroded Area covers $1256 \mathrm{~km}^{2}$. The Irangi Hills forms the largest part of KEA [5]. The altitude of the Irangi Hills ranges from 1200 to $2000 \mathrm{~m}$ above sea level. The climate of Kondoa District is semiarid, characterised by an average annual rainfall of between 600 and $800 \mathrm{~mm}$, with a long-term average of $640 \mathrm{~mm}$ per year [5]. However, in the more elevated parts of the Irangi Hills up to $900 \mathrm{~mm}$ of rain have been recorded [26]. The rainfall season is usually between November and April/May, with a dry spell in February. The period between May and October is usually dry. The rainfall pattern in this area is highly variable and most of the precipitation occurs in short duration storms. The district is characterised by high evapotranspiration rates that double the amount of precipitation [27].

The majority of soils in the semiarid areas of central Tanzania originate from granitic, gneissic and schistic parent material. These soils are of low fertility, base-exchange capacity, bulk density and water-retention capacity [6]. These soils also have low organic matter content, a condition that makes them extremely erodible [7]. The Irangi Hills are severely affected by soil erosion. Studies on soil erosion in the area indicate rates of between 27 and $37 \mathrm{t} \mathrm{ha}^{-1} \mathrm{yr}^{-1}$ [28], in the sub-humid and semiarid parts of the hills respectively. The soils in Irangi Hills are generalised as coarse loamy to sandy loams in texture, being sandiest in the surface horizon. This implies the need for proper management in order to sustain agricultural productivity. Different strategies used by farmers in KEA, for instance, in coping with poor soil fertility have been described by Kangalawe [1, 29].

Soil conservation initiatives started in Kondoa district since the colonial administration in the 1930s. During the 1940s to 1950s soil conservation involved measures such as reduction of livestock numbers, ridge cultivation, contour bunding of uncultivated land, rotational grazing and gully erosion control [30]. Farmers were also required to plant sisal around farmlands to save the arable land from further destruction.

Soil conservation measures during that period were associated with colonial force, where some of the activities were assigned to people as punishment for disobedience of local rulers and tax aversion. They were thus considered as an interference with local traditions and became quite unpopular [4]. In 1973 the government of Tanzania started a state-run soil conservation project in Dodoma region, popularly known as HADO (Hifadhi Ardhi Dodoma). This was a deliberate attempt to come to grips with the menace of soil erosion and degradation in the region [5]. Three kinds of approaches were undertaken to enhance soil conservation, including mechanical, biological and administrative measures [4]. Mechanical measures involved barriers such as terraces and earth banks across the slopes that were built to slow down surface runoff. Biological measures involved earth binding with plantations of different kinds, such as grass strips across the slope, planting grass in sandy rivers and in gully bottoms, rotation of crops, and the spread of residue on the fields. The 
administrative measures encompassed tree planting demonstration plots, organising grazing and farming techniques such that the land is protected as much as possible. These measures were complemented by evacuation of all domestic animals in 1979 [5]. Expulsion of livestock from the Irangi Hills in 1979 as part of soil conservation approaches instituted in the KEA resulted in ecological transformation from the heavily browsed shrubs and scattered trees to impressive regeneration of herbaceous, woodland and woody shrubs, as well as grassland vegetation cover. Economically, however, this agro-pastoral society was no longer able to depend on livestock as a form of capital, or as a security against the harsh climatic conditions of the region.

\section{Methodology}

\subsection{Sampling procedure}

The Kondoa Eroded Area (KEA) covers twenty-eight villages. A list of these villages was made and three of them were selected at random, namely Mafai, Baura and Bolisa. The selected villages had 370, 350, and 750 households respectively. The selected villages are subdivided into sub-villages for administrative purposes. To allow for adequate representation, $10 \%$ of households from each sub-village was randomly selected for inclusion in the sample. A total sample of 147 households was selected for interviews. A random sampling procedure was employed in selecting the sample households from lists of household heads that were made for each of these villages. Sampling is a common practice in research. The random sample of $10 \%$ of the villages and households selected for this study is considered to be representative enough for statistical analysis [31]. Under certain circumstances, such as resource constraints, even a smaller sample of $5 \%$ is regarded as being representative enough [32].

\subsection{Data collection and analysis}

Household interviews, using a standard questionnaire, were the major means used to collect both qualitative and quantitative information. The questionnaire survey was complemented by informal surveys that involved discussions with key informants, including village leaders, extension workers, district agricultural officials and HADO staff. These informal surveys were conducted in order to get some general overview on soil degradation, community perceptions and agricultural performance in general. These surveys also provided a means and direction in crosschecking the responses from formal interviews. The key informants were found in the respective villages and/or at district level. Information from key informant interviews was analysed by triangulation with all other sources. To determine the level of awareness of soil degradation three exploratory questions were asked. Firstly, whether the study community perceived land/soil degradation as a problem in their villages. Secondly, what criteria are used by this community to determine the quality of land/soil in general. Thirdly, whether they associated land/soil degradation with crop cultivation or livestock management systems of the area. These aspects are addressed in the following sections. 
The surveys were complemented by field observations in farmers' fields. Field visits involved observations of various land degradation features, such as soil erosion and sedimentation, surface runoff, sandiness of soils, crop vigour, presence of indicator-plant species; and agricultural practices, including among others, types of crops grown, cropping patterns and on-farm soil conservation measures. Field observations also included sampling soils from selected transects for subsequent laboratory analysis of soil nutrients. Three farmer-led transect walks were undertaken with small groups of farmers in each village and soil samples were collected from representative sites of major soil groups as identified by farmers. Soil profile pits were dug to a depth of one meter and samples taken at $20 \mathrm{~cm}$ intervals [33]. A total of eighty samples were collected for analysis. Nutrient content of the soil was determined to provide an estimate of the inherent soil fertility status and for soil nutrient balance assessment. The data was analysed using statistical measures of central tendency (means), and frequency distribution (percentages) [34, 35]. The frequency distribution data was cross-tabulated into contingency tables.

\section{Results and discussion}

\subsection{Community' perceptions on land/soil degradation}

\subsubsection{Local perceptions of soil degradation}

Response to the inquiry on whether the study community perceived soil degradation as a problem in their villages have shown that $58 \%$ of the respondents considered soil degradation as being a serious problem in their vicinities. This perceptions may be influenced by differences in socio-economic characteristics inherent among the local people. Socio-economic characteristics such as endowment of livelihood assets by households determine the ability of a household to use, for example, agricultural inputs like fertilisers or manure as a way of improving soil productivity. In the Irangi hills, for instance, wealthy farmers who could afford using fertilisers and/or manure did not perceive soil fertility as a major issue. Those who perceived soil degradation as a problem mentioned the generally low but declining soil fertility of the Kondoa soils, soil erosion and runoff, sandiness of soils and sedimentation as key indicators of soil degradation in their villages. Figure 2 presents the proportions of responses on indicators of farmers' awareness of soil degradation processes.

The small percentage of respondents mentioning soil erosion in Mafai village could be attributed to that this village is surrounded by a protected catchment forest and is generally less degraded compared to the other two villages. The presence of these indicators seem to show that rural people are aware of their environment and its related problems, and particularly so with those which affect the farm productivity and/or those that resulted into more visible landscape changes such as soil erosion. However, the fact that less than half of the respondents indicated that soils are inherently infertile suggests that productivity has declined significantly within living memory and that people were unaware that their yields were probably rather low from the outset. It is explained by Tosi et al. [36] that the low inherent soil 


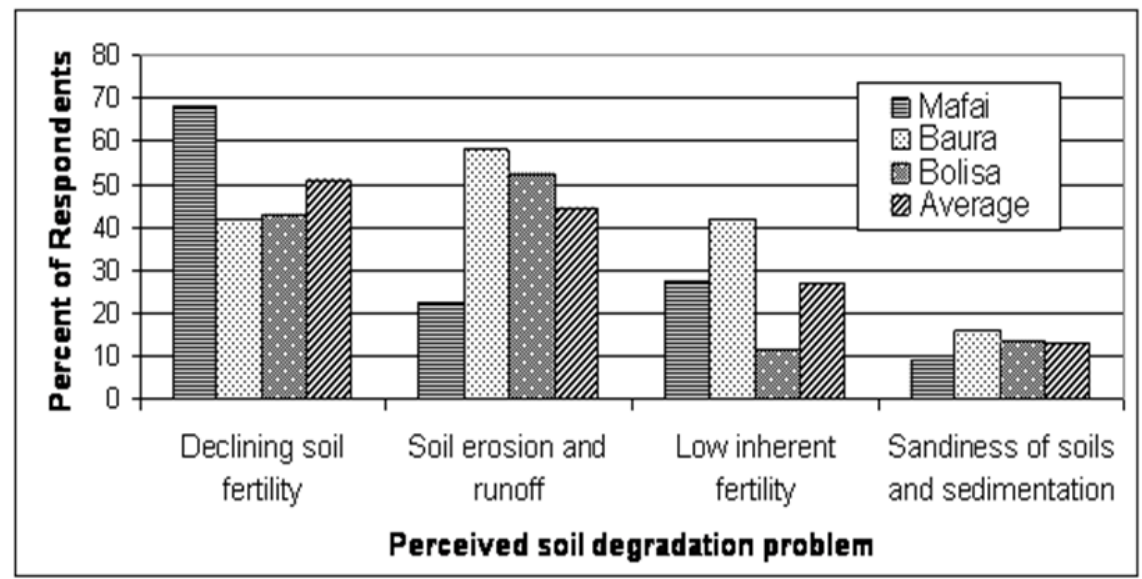

Figure 2. Percent responses on community awareness of soil degradation problems.

fertility is attributed to parent material factors. Soils in this area are reported to have formed from metamorphic and igneous rocks which are poor in plant nutrients. The dry climatic condition of the study area also limits high productivity of organic matter, resulting in poor surface cover and low incorporation into the soil as binding agent and for fertility enhancement [37].

Declining soil fertility was perceived as the major indicator of soil degradation in the studied villages. A majority of the farmers $(80 \%)$ attributed such decline to continuous cultivation without resting the fields, whereas $20 \%$ ascribed it to inadequate application of manure and/or fertilisers. One explanation to continuous cultivation was the increasing land shortage that has led to intensified crop cultivation and short or no fallow periods. Studies conducted in neighbouring villages and in other parts of the Irangi Hills also revealed that most farms are cultivated every season without fallow and are thus subjected to continuous loss of soil fertility $[1,38]$.

The general assessments of soil fertility in Kondoa District that soils in the area are of low fertility $[1,7,39,40]$. Results from laboratory analyses for soil nutrients (Table 1 ) confirm the low levels of soil nutrients in all the three villages studied. These results also indicate that Mafai soils had more advantage in terms of nitrogen content than both Baura and Bolisa. These soils had about four times as much total nitrogen as Baura and Bolisa, whereas Baura had soils richer in available phosphorus than the other two villages. The variations in nutrient contents may be attributed to, among other factors, the severity of soil degradation that characterises the studied villages and different management practices of the farms. Many soil conservation structures like contour bunds and planted trees were also observed in Mafai compared to the other two villages. Soils in Mafia village are less eroded, hence have more nutrients in the sampled surface layer attributable to presence of higher organic matter content. A large part of the village is covered by a protected catchment forest and generally less severely degraded compared to Baura and Bolisa. 


\begin{tabular}{lccc}
\hline Soil characteristic & Mafai & Baura & Bolisa \\
\hline $\mathrm{pH}\left(\mathrm{H}_{2} \mathrm{O}\right)$ & 4.80 & 5.20 & 5.40 \\
Total Nitrogen (\%) & 0.29 & 0.07 & 0.08 \\
Available P (ppm) & 4.20 & 7.20 & 3.20 \\
$\mathrm{CEC}$ me/100g & 17.12 & 3.84 & 13.89 \\
Exchangeable K (me/100g) & 0.61 & 0.61 & 0.52 \\
Exchangeable $\mathrm{Ca}(\mathrm{me} / 100 \mathrm{~g})$ & 4.39 & 1.83 & 2.74 \\
Exchangeable $\mathrm{Mg}(\mathrm{me} / 100 \mathrm{~g})$ & 1.61 & 0.40 & 1.20 \\
Exchangeable $\mathrm{Na}(\mathrm{me} / 100 \mathrm{~g})$ & 1.86 & 0.92 & 0.80 \\
Organic carbon $(\%)$ & 2.62 & 0.31 & 0.54 \\
Particle size & & & \\
\% Sand & 54.83 & 80.27 & 69.20 \\
\% Silt & 14.57 & 10.60 & 17.63 \\
$\%$ Clay & 30.60 & 9.13 & 13.17 \\
\hline
\end{tabular}

Table 1. Some characteristics of soils from the study area (measured at $0-20 \mathrm{~cm}$ depth)

Soil erosion and surface runoff featured as indicators of soil degradation as indicated by about $44 \%$ of respondent farmers (Figure 2). Awareness of soil erosion as a soil degrading process featured more prominently among Baura and Bolisa respondents. Visual observation of the landscape in these villages confirms the local people's response. Both Baura and Bolisa have landscapes dissected by more pronounced gullies (Figure 3) compared to Mafai village (Figure 4). Discussions with key informants in these villages indicated that historically the two villages had large numbers of livestock prior to destocking in 1979 that rendered many places devoid of vegetation because of overgrazing. This situation exposed the land surface to agents of soil erosion, such as runoff. The extensive gullies seen today in these and many other villages in the Irangi Hills are said to have formed along former cattle tracks aligned down the slope [6].

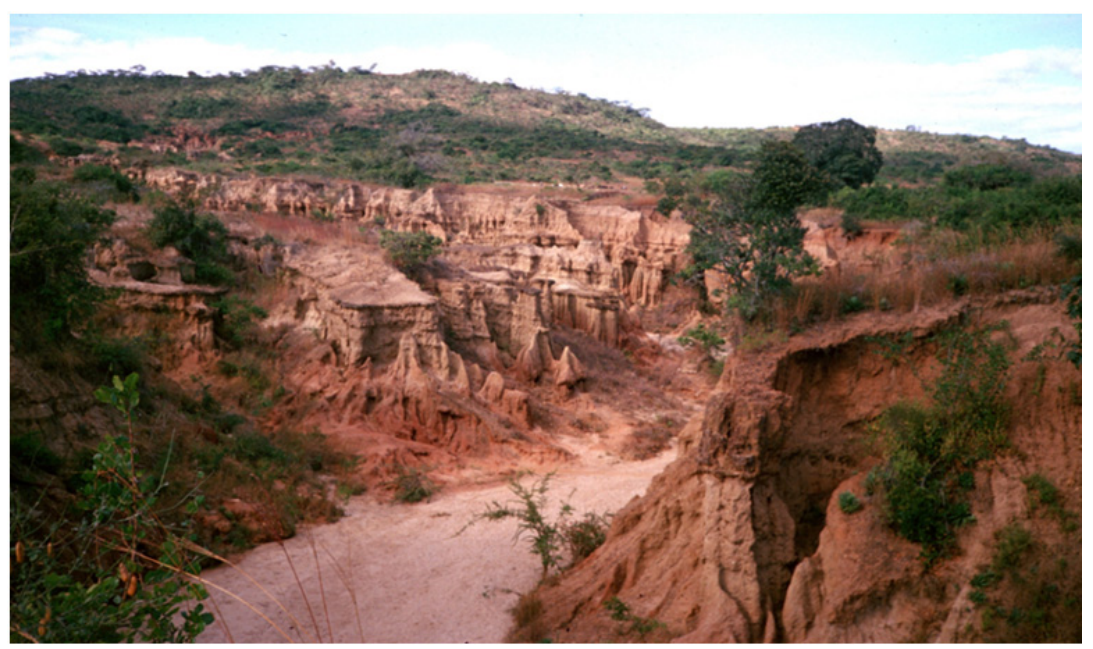

Figure 3. Gully erosion in the studied villages. This is a common feature of the landscape and in many parts of the Kondoa Eroded Area 


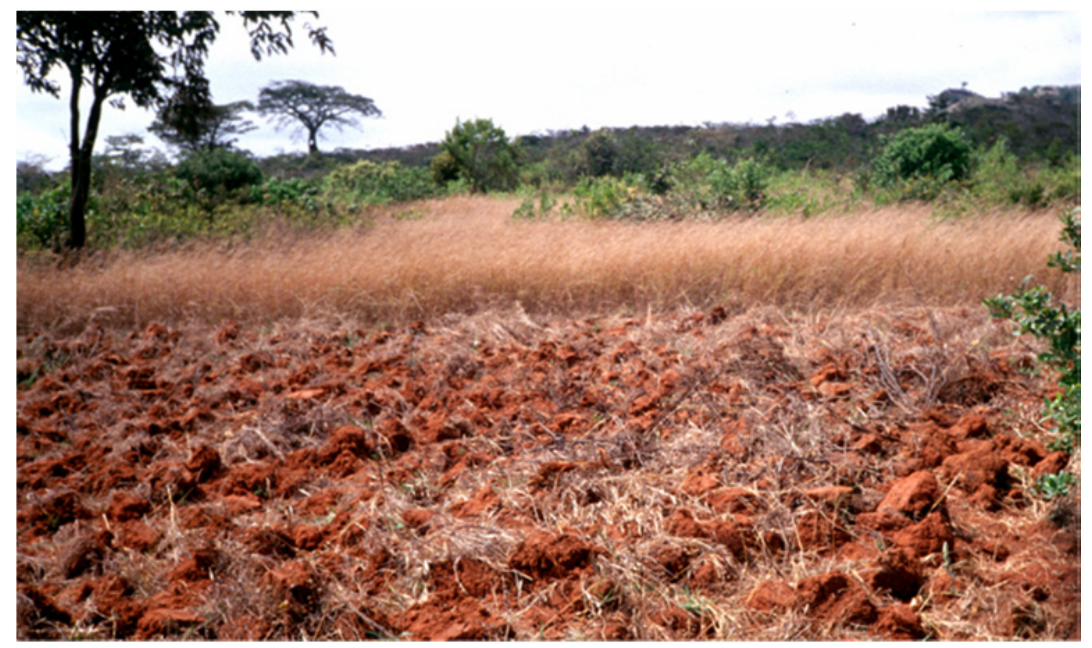

Figure 4. An uneroded part of the landscape wihin the Kondoa Eroded Area.

Sedimentation and sandiness of the soil was perceived as a problem by only a few farmers (see Figure 2). This response was particularly obtained from farmers whose fields laid in stabilising sandfans that have soils with very low organic matter levels, low moisture holding capacity and poor fertility status. Such soil characteristics are also common in other parts of the Irangi Hills, such as in Haubi and Mulua [1,7]. Sedimentation was reported to take place in depositional footslopes and valley bottoms where the eroded materials from hillslopes accumulate. In many places sedimentation of sandy materials buried the former fertile clayey topsoil [1,7]. One would expect this indicator to be mentioned by most respondents, however since farmers have had their settlements and fields in that kind of environment for generations they do not often mention it as a major concern. The explanation to this situation would be that soil erosion and sedimentation in this area dates long in history to the extent that very few benchmark areas remain that could show the earlier landforms not affected by sedimentation [7].

\subsubsection{Assessing land and soil quality}

Findings from this study showed that there are several traditional ways communities use to evaluate and to explain the quality of the land and the soils they are cultivating. Three categories of responses appeared to be most prominent, namely crop vigour and crop yields, presence of indicator-plant species and density of vegetation under fallow [29].

A healthy and vigorous crop growth, reflected by a good crop stand in the field, was used as an important indicator that the soil is fertile enough, if moisture and other factors are not limiting [29]. Under such circumstances, even if the weather conditions worsen during the growing season such that final yields are poor, the farmer would have realised the potential fertility of a certain piece of land. A stunted crop with less vigorous growth in the field when other factors such as moisture are considered not limiting was locally perceived to 
indicate a high probability that soils on which the crop is growing are of low quality and infertile.

Majority of respondents (95\%) considered crop yields as the best measure to comprehend land/soil quality. It was noted that low or declining crop productivity could be a clear indicator of declining soil fertility, and hence soil degradation. The use of this indicator by the local farmers in evaluating land/soil quality is also appreciated by experts in land degradation, where crop output decline is regarded as a proxy indicator of soil degradation in farmlands [1, 40,41]. It is particularly important because it affects people directly in terms of food availability and security. However, this factor alone is not sufficient to establish that degradation is taking place since cropping conditions vary considerably between years and between individual farmers. The influence of other factors such as crop pests and diseases and climate variability may affect crop yields [42, 43]. In the Irangi Hills most of the respondents indicated also that low crop yields could be due to low and/or erratic rainfall. This aspect needs to be investigated further to establish detailed linkages between climatic patterns and crop yield trends in the area. Nevertheless crop yields are an important indicator of proximate soil conditions if other factors are not constraining.

\subsection{Locally perceived association between farming systems and soil degradation}

Table 2 presents the locally perceived relationships that were cited by the respondents as being the contribution of the farming practises to the observed land/soil degradation in the study areas. About $52 \%$ of the respondents associated soil degradation to continuous cropping while $23 \%$ considered inadequate manure application to be responsible for the diminishing soil quality. The overuse of the soil in continuous tillage without fertiliser supplementation, coupled by grazing on plant residues, weeds and crop stubble, has deprived the soils of both nutrients and organic matter [1, 29].

\begin{tabular}{lcccc}
\hline Perceived Relationship & $\begin{array}{c}\text { Mafai } \\
(\mathrm{n}=28)\end{array}$ & $\begin{array}{c}\text { Baura } \\
(\mathrm{n}=26)\end{array}$ & $\begin{array}{c}\text { Bolisa } \\
(\mathrm{n}=42)\end{array}$ & $\begin{array}{c}\text { Total } \\
(\mathrm{n}=96)\end{array}$ \\
\hline Continuous cropping & 57.1 & 30.7 & 61.9 & 52.1 \\
Lack or inadequate availability of manure & 10.7 & 53.8 & 11.9 & 22.9 \\
Overgrazing in the past decades & 14.3 & 11.5 & 11.9 & 12.5 \\
Cultivation on steep slopes & 14.3 & 4.0 & 4.8 & 7.3 \\
Lack of on-farm conservation measures & 3.6 & 0 & 9.5 & 5.2 \\
\hline
\end{tabular}

Table 2. Perceived relationships between cropping/livestock management systems and soil degradation in the Irangi Hills (\%)

Overgrazing was pointed out to be one of the processes that facilitate degradation by $12.5 \%$ of respondents. The low figure is explained by the fact that to the Rangi community, which is traditionally agro-pastoralist, having big herds of livestock is just part of their culture thus locally overgrazing is rarely seen as a major problem. A similar explanation regarding perceptions on overgrazing has been reported recently among communities in the Sukumaland and in the Iramba area $[42,44]$. Overgrazing of livestock had similar effects on 
the soils of steep slopes and on shallow and stony soils, where continuous cultivation has not been practised [36]. Lack of on-farm conservation measures, especially before HADO started its activities, significantly contributed to the degradation features witnessed in the present days $[1,7]$. Thus elaborate extension services are probably needed regarding various mechanisms that may contribute to sustainable farm production, such as on-farm erosion control, agroforestry practices and proper residue management. Proper farmer education would inculcate the culture of conservation among communities. Other associations presented in Table 2 did not feature as important concerns among farmers, but because of their role in soil degradation they are worth some attention.

While incorporation of crop residue and manure were meant to improve organic matter content and replenish soil fertility in the farm, contour ridges were constructed to check runoff and control erosion, and as such prevent further loss of soil fertility through nutrients washed away in eroded soil material. Only limited quantities of manure were however applied per unit area, especially since 1979 when livestock were evicted from the KEA. The limited supplies of manure and the high fertiliser prices are responsible for their low usage as adaptive mechanisms in fighting against soil degradation at farm level [29]. The only reliable way of replenishing soil fertility has been through crop residue incorporation into the soil. However, during dry seasons the residue provides valuable feed for livestock, whereas considerable proportions are burnt when preparing the land for a succeeding crop hence not much residue is left for incorporation into the soil. This may have negative consequences on subsequent crop productivity. Similar experiences are reported for other parts of the Irangi Hills, for example in Haubi and Mulua villages [1].

\subsection{Community involvement in land resource management}

\subsubsection{Community participation in soil conservation}

The pressure on land has practically increased all over the country particularly during the $20^{\text {th }}$ century as a result of population growth. This has, in many instances resulted in unsustainable cultivation techniques including shortened fallow periods [38, 45] that consequently impoverish the soil. Enhanced long-term productivity and sustainability of the land resource thus require sound soil conservation measures in the farming systems that enhance maintenance and/or improvement of soil and land quality in general. This is an important consideration as it influences agricultural productivity and local livelihoods.

In many instances environmental degradation has stimulated a variety of responses and adaptation mechanisms by local communities. This study made an enquiry on whether farmers had undertaken any deliberate efforts to protect their land holdings from soil degradation. Majority of respondents (95\%) indicated to have used one or more conservation techniques in their farms as a means of adjusting and adapting to soil degradation processes. Table 3 presents the various soil conservation approaches as mentioned by the interviewed farmers. The first three combinations of approaches, that is, contour ridges; tree, sisal and grass planting; manure application and incorporation of crop 
residue in soils, appeared to be the most prominent conservation strategies adopted by majority of farmers who were practising conservation, accounting for $97 \%$ of farmers in Mafai, $85 \%$ in Baura and $81 \%$ in Bolisa village. The generally sloping terrain in Mafai village partly explains the reported increase in the use of contour ridges, trees, sisal and grass planting to protect the soil from erosion.

\begin{tabular}{lcccc}
\hline Measures taken & $\begin{array}{c}\text { Mafai } \\
(\mathrm{n}=35)\end{array}$ & $\begin{array}{c}\text { Baura } \\
(\mathrm{n}=34)\end{array}$ & $\begin{array}{c}\text { Bolisa } \\
(\mathrm{n}=70)\end{array}$ & $\begin{array}{c}\text { Total } \\
(\mathrm{N}=139)\end{array}$ \\
\hline Contour ridges; tree, sisal and grass planting; Manure & 80 & 55.9 & 68.5 & 68.1 \\
application and Incorporation of crop residues in soils & & & & \\
Contour ridges and tree planting & 17.1 & 29.4 & 12.9 & 19.8 \\
Tree planting only & 0 & 5.9 & 12.9 & 6.3 \\
Stall-feeding cattle & 2.9 & 5.9 & 4.3 & 4.4 \\
Crop rotation & 0 & 2.9 & 1.4 & 1.4 \\
Total & 100 & 100 & 100 & 100 \\
\hline
\end{tabular}

Table 3. Soil conservation measures undertaken by respondent farmers (in \%)

A majority of farmers have also planted trees as one of the soil conservation practices advocated by HADO. Table 4 presents a list of tree species that are planted in the study area and associated uses. As for crop rotation, the low response reported in Table 3 was mainly attributed to the small farm holdings that necessitate farmers to practice continuous cultivation of same fields.

\begin{tabular}{lcccccc}
\hline Name & Scientific name & Purpose $^{1}$ & $\begin{array}{c}\text { Mafai } \\
(\mathrm{n}=31)\end{array}$ & $\begin{array}{c}\text { Baura } \\
(\mathrm{n}=31)\end{array}$ & $\begin{array}{c}\text { Bolisa } \\
(\mathrm{n}=67)\end{array}$ & $\begin{array}{c}\text { Total } \\
(\mathrm{N}=129)\end{array}$ \\
\hline Silk oak & Grevillea robusta & $\mathrm{Ct}, \mathrm{Fw}, \mathrm{Fi}$ & 87.1 & 90.3 & 95.5 & 91.0 \\
Guava & Psidium guajava & $\mathrm{Fr}$ & 51.6 & 51.6 & 49.3 & 50.8 \\
Pawpaw & Carica papaya & $\mathrm{Fr}$ & 29.0 & 29.0 & 76.1 & 44.7 \\
Lemon & Citrus limon & $\mathrm{Fr}$ & 19.4 & 22.6 & 17.9 & 20.0 \\
Orange & Citrus sinensis & $\mathrm{Fr}$ & 25.8 & 0 & 26.9 & 17.6 \\
Eucalyptus & Eucalyptus sp. & $\mathrm{Fw}, \mathrm{Ct}$ & 35.5 & 3.2 & 1.5 & 13.4 \\
Mango & Mangifera indica & $\mathrm{Fr}, \mathrm{Sh}$ & 0 & 16.1 & 14.9 & 10.3 \\
Pomegranate & Punicum granatum & $\mathrm{Fr}$ & 3.2 & 3.2 & 11.9 & 6.1 \\
Leucaena & Leucaena leucocephala & $\mathrm{Fd}, \mathrm{Fi}$ & 3.2 & 3.2 & 1.5 & 2.6 \\
Cypress & Cuppressus sp. & $\mathrm{Fi}, \mathrm{Ct}$ & 3.2 & 3.2 & 0 & 2.1 \\
Iron wood & Senna siamea & $\mathrm{Ct}, \mathrm{Fw}$ & 0 & 3.2 & 1.5 & 1.6 \\
\hline
\end{tabular}

${ }^{1} \mathrm{Ct}=$ construction material/timber, $\mathrm{Fr}=$ fruits, $\mathrm{Fd}=$ fodder, $\mathrm{Fi}=$ soil fertility improvement, $\mathrm{Fw}=$ fuelwood, $\mathrm{Sh}=$ shade.

Table 4. Tree species planted in the study area, ranked according to preferences and percent of respondent farmers that have planted them

Findings from this study are in agreement with studies elsewhere that farmers often attempt to adjust to environmental degradation by using various measures and strategies [19, 46]. The measures taken may be different depending on the natural environment and socio- 
cultural backgrounds of the area concerned. According to Nsiah-Gyabaah [19], farmers' adjustment to their environment can generally be effective when they are able to predict the short term inter-annual variability patterns (e.g. in soils and weather). Under such situation they may be able to successfully use available innovations and local expertise to maximise the benefits of both soils and weather. However, where changes are unpredictable farmers may face difficulties in establishing adaptation mechanisms.

\subsubsection{Challenges to community participation in soil conservation practices}

Community participation in conservation practices is of great importance as it seeks to guarantee access and control over resources by the communities living in them, but who depend on these resources to satisfy their various needs (ecological, economic, social, cultural and spiritual needs). Community participation ensures more commitment in ensuring that resources are more sustainably managed, where apart from communities depending on these resources for a living and conserving them, they at the same time become their guardians $[47,48]$. The active participation of various stakeholders in decisionmaking is crucial for ensuring the long term sustainability of community-based resource management initiatives. In several occasions however, soil conservation has not received the expected involvement of local communities. Some of the reasons that have influenced the local people's attitudes towards land/soil conservation efforts in the Irangi Hills are discussed here.

One of the reasons put forward was the tendency to underestimate the seriousness of the soil erosion problems by many people in the area. Where the tenure system is not elaborate individual farmers may not be concerned with problems of land degradation regardless of their holdings being at risk as such land degradation is considered as a general community problem. Such attitudes may result in no action being taken against land degradation even when there are no clear hindrances. The implication of the foregoing is that effective conservation is likely to be achieved when land tenure systems are properly articulated [1]. Thus efforts are needed to ensure integrated community-level planning that could promote individual farmers efforts without undermining community interests. Recent experiences from studies in Kishapu and Kahama Districts in Shinyanga Region, and in Nyarugusu area in Geita District Mwanza region indicated that many people practice soil and water conservation mainly in their own lands/farms [42], including setting aside private conservation areas such as Ngitili [49]. Adoption and/or practicing certain conservation measures are much influenced by the farmer's economic situation, including resource endowments. For instance, farmers with sufficient land holdings can afford to conserve some of it under the Ngitiri system, while land constrained farmers may not. Similar experiences would be the case for other conservation measures that require heavy investment by the farmer, for example making of soil erosion control structures that may need additional labour, and using fertilisers and/or manure.

Apart from the underestimation of the land degradation problem and inarticulate tenure system, it is also evident that the Rangi people themselves are traditionally not 
conservationists. When the pressure on land increases and harvests dwindle, some villagers will leave to take up new land elsewhere while others remain. The Rangi as a group can be said to practice an expansionist permanent agriculture [2]. Their principal solution to problems of soil erosion, for example, has thus been to move temporarily or permanently to areas with better conditions, while also retaining a foot in the Rangi core areas $[2,50,51]$.

Experiences from the Irangi Hills and elsewhere in East Africa indicate that resource management is closely influenced by the prevailing socio-political environment [52]. It was reported, for instance, that some people in the Irangi Hills were of the opinion that the low adoption of soil conservation measures was based on negative attitudes that were inculcated among people during the colonial era, when such activities were basically coercive [1, 29]. During the colonial period soil conservation was seen as a form of oppression [50,53]. In Kenya, for example, soil conservation was made compulsory under colonial administration and forced labour was used for community conservation programmes [22]. Although some of the soil conservation techniques employed were effective (e.g. in Machakos district), the coercive methods used were very unpopular [4, 22, 53] resulting into some local communities withholding their own conservation initiatives. This was also experienced in the Irangi Hills and among other communities in Kondoa District [50].

In the Kondoa case, the opposition to conservation during the 1940s was closely linked to a wide discontent within the Rangi community with the way the colonial government appointed local leaders. Thus a more explicit political discourse (struggle against colonialism) became linked to soil conservation policies [50]. Consequently, during the nationalist struggle in the late 1950s it was no longer possible to enforce communal turnout and most conservation work came to a halt [54]. The Kondoa Chief of the time came to side with the Rangi underground opposition against regulations on land-use. It is not surprising then that even independent governments found it difficult to reverse the previous nationalist attitudes and support conservation measures [22,53]. Land degradation was thus left to continue. These experiences reflect to the need for local community participation in developing and implementing resource management strategies.

\subsection{Land-use dynamics and environmental degradation}

\subsubsection{Land availability over time}

In general, there have been changes in land-use use types in the study area due to several factors. Such changes can be considered to be adaptive mechanisms to population growth, economic development and to changing climate. Population growth is usually associated with increased exploitation of natural resources. According to local knowledge in the study area, prior to Tanzania's independency in 1961, arable land for agriculture and livestock was relatively plenty and used for different purposes, including cultivation and livestock grazing. The increase in population has led to expansion of agricultural and livestock activities. This has contributed significantly to changes in land-use intensity and cover types. 
An assessment was made on perceptions regarding land availability over three time periods, from post independence, villagisation and current period. Experiences from the selected villages indicated that during post independence and villagisation period agricultural land was fairly easily available at the areas close to homesteads. It was reported that, land availability is currently very difficult than ever before, the main cause being increase in population pressure, which has led to increased demand for land by villagers. Eventually this has created land shortage in most of the villages. The pattern of land availability over years is also experienced in other parts of Kondoa District [55]. Farmers reported that currently the places with easily available land are those located far from homesteads, which was considered to be a major limitation for people who are not able to manage distant farms.

\subsubsection{Decreasing farm sizes}

For arable land use, there has been a general decline in the farm sizes. The local people attributed the decline in the farm sizes to several other factors (see Table 5). Thus there is a concern that land is increasingly being insufficient. The big proportion of the people reporting to experience land shortage reflects to that the problem of land shortage is much bigger than currently envisaged, and may worsen particularly with the fast growing population.

\begin{tabular}{|l|c|}
\hline Perceived cause declining farm sizes & Percent \\
\hline High population growth/increase & 80.3 \\
\hline Expansion of settlements & 6.9 \\
\hline Soil erosion and gullies & 4.0 \\
\hline Expanding livestock keeping (more livestock) & 2.9 \\
\hline Expansion of family sizes & 2.0 \\
\hline Low soil fertility - land is tired/exhausted & 2.0 \\
\hline Tree conservation & 0.9 \\
\hline Intensive rainstorms (more erosion) & 0.9 \\
\hline Total & 100 \\
\hline
\end{tabular}

Table 5. Different factors considered by the local community to cause declining farm sizes

The decreasing farm size is one of the causes of household food insecurity in the area. The small farm sizes limit the possibilities to practice fallow rotation. Consequently continuous cultivation culminates into declining soil fertility and reduced crop productivity. The problem may as well be aggravated by loss of land as a result of soil erosion, particularly gully erosion.

\subsubsection{Chancing land use patterns and local adaptive mechanisms}

Experiences on land use and the way rural land users interact with environmental resources show that communities have increasingly interacted with their local environment by 
faltering land use practices. However, continued land degradation has had severe environmental and social-economic consequences resulting in poor agricultural productivity, perpetuating food insecurity and poverty among the concerned communities. This necessitates the analysis of land-use dynamics, land degradation and their interlinkages with livelihoods and poverty alleviation strategies adopted by the respective communities. Generally, there have been changes in land use patterns, which in many instances has involved increasing land use intensity as adaptive mechanisms to increased population growth, economic development and to changing climate [25]. Increase in population has led to expansion of agricultural and livestock activities, contributing significantly to changes in land use intensity, decline in farm sizes, land fragmentation and land degradation. Sustainable management of natural resources can thus be achieved by having integrated land use practices, including developing elaborate village land use plans.

Livelihood diversification into non-agricultural enterprises was also reported to have been a means of adapting to the changing environments and for poverty alleviation. Diversification as applied in the rural context is a process whereby rural households construct an increasingly diverse portfolio of activities and assets in order to survive [56]. Diversification can be viewed from different angles. It may imply a matter of survival associated with harsh local environmental conditions, or alternatively, it may be considered a matter of opportunity involving pro-active household strategies employed to improve living standards [57]. Generally, however, a diversity of livelihood sources is considered to be one of the ways through which households may develop security against agrarian environments, particularly in semiarid areas.

\section{Conclusions}

This chapter has examined how perceptions and knowledge facilitate and/or act as barriers to sustainable land management. It has been realised that farmers in the Irangi Hills are aware of land/soil degradation and its various processes, with levels of perception varying between villages and among respondents depending on the severity of the land degradation problem. Declining soil fertility and soil erosion, demonstrated by existence of spectacular gullies and extensive depositional sand fans, have been found to contribute significantly to the general understanding of land/soil degradation problems.

Awareness of land degradation was also reflected by the various criteria that the local people use in assessing the potentials and constraints that farmlands and the landscape in general are facing. Low crop productivity has been identified as one of the important constraints; attributed mainly to declining soil fertility, unreliable rainfall, and to a lesser extent, soil erosion. Farmers seemed to be quite aware of the association between cropping and/or livestock management systems and land/soil degradation. An extension service focusing on the various mechanisms that may contribute to sustainable farm production, such as on-farm erosion control, agroforestry practices and proper residue management is necessary. This is particularly important in a situation where continuous cultivation has become the norm because of increasing land shortage. Thus the various adaptations that 
farmers are already exposed to with regard to improving agricultural productivity in the erosion-stricken farmlands need to be promoted and developed further.

Limiting factors to local participation in soil conservation initiatives would probably be successfully corrected through proper farmer education that inculcates the culture of conservation among communities. It is important therefore that steps are taken to address the diversity of the intricate attitudes and socio-political environments among rural communities. It is recommended that further comparative studies be conducted so as to come up with sound strategies that will motivate the local people to participate more in issues related to sustainable land resource management. Where relevant such strategies and approaches to extension work need to be tailored to individual communities rather than using large homogenous programmes.

Increase in population has led to expansion of agricultural and livestock activities, contributing significantly to changes in land use intensity, decline in farm sizes, land fragmentation and land degradation. Since agricultural production (crops and livestock) is the major means of poverty alleviation in these semiarid areas, it calls for enhanced environmental conservation so that agricultural productivity can be sustained for the betterment of the community livelihoods. This is particularly important now given the additional factor of climate change. Thus, sustainable management of land and other natural resources can only be achieved by having integrated land use practices, including developing elaborate land use plans. Poverty alleviation strategies and other policies also need to ensure sustainable development with minimal impacts on the environment. The diversification of livelihood activities (farm and non-farm) recorded in the area indicates that local communities are struggling towards poverty alleviation and as a way of adaptation and coping to environmental degradation.

\section{Author details}

Richard Y.M. Kangalawe

Institute of Resource Assessment, University of Dar es Salaam, Dar es Salaam, Tanzania

\section{Acknowledgement}

This study was undertaken with a financial support from NORAD through its Management of Natural Resources and Sustainable Agriculture fellowship programme. Many thanks are extended to the farmers in Bolisa, Baura and Mafai villages who enthusiastically participated in this study and for their inspirations that paved a way towards completion of this work.

\section{References}

[1] Kangalawe RYM. (2001) Changing land-use patterns in the Irangi Hills, central Tanzania: A study of soil degradation and adaptive farming strategies. PhD Dissertation No. 22. 
Department of Physical Geography and Quaternary Geology, Stockholm University: Stockholm.

[2] Östberg W (1986) The Kondoa Transformation: Coming into Grips with Soil Erosion. Research Report No. 76. Scandinavian Institute of African Studies: Uppsala.

[3] Christiansson C, Kikula IS, [51] W (1991) Man-land interrelations in semiarid Tanzania: A multidisciplinary research programme. Ambio 20 (8): 357-361

[4] Christiansson C, Mbegu A, Yrgård A (1993). The Hand of Man: Soil conservation in Kondoa Eroded area, Tanzania. Nairobi: Regional Soil Conservation Unit.

[5] Mbegu AC (1988). The HADO Project: What, Where, Why, How? Forestry and Beekeeping Division, Ministry of Lands, Natural Resources and Tourism: Dar es Salaam.

[6] Payton RW, Christiansson C, Shishira EK, Yanda P, Eriksson MG (1992) Landform, Soils and Erosion in the north-eastern Irangi Hills, Kondoa, Tanzania. Geografiska Annaler 74 (A 241): 65-79

[7] Payton RW, Shishira EK (1994) Effects of soil erosion and sedimentation on land quality: Defining pedogenetic baselines in the Kondoa District of Tanzania. In: Syers JK, Rimmers DL. Editors. Soil Science and sustainable land management in the tropics. England: Wallingford CAB International 88-119.

[8] Darkoh MB (1986) Experiences of arid land development in Tanzania: In: Arid land development and the combat against desertification: An integrated Approach. UNEP: Moscow.

[9] Eriksson MG (1998) Landscape and soil erosion history in central Tanzania. A study based on lacustrine, colluvial and alluvial deposits. Dissertation No.12. Department of Physical Geography, Stockholm University: Stockholm.

[10] Eriksson MG, Olley JM, Payton RW (1999) Late Pleistocene colluvial deposits in central Tanzania, erosional response to climate change. GFF 121:198-201

[11] Eriksson MG, Olley JM, Payton RW, (2000).. Soil erosion history in central Tanzania based on OSL dating of colluvial and alluvial hillslope deposits. Geomorphology 36: 107-128

[12] Ngana JO (1996) Climate and hydrology of the Kondoa Eroded Area. In: Christiansson C., Kikula IS. Editors. Changing Environments: Research on Man-Land Interrelations in Semiarid Tanzania. Report No. 13. Nairobi: Regional Soil Conservation Unit:.

[13] Whyte AVT (1977) Guidelines for field studies in environmental perception. MAN Technical Notes No 5. Paris: UNESCO.

[14] Hackel JD (1990) Conservation attitudes in southern Africa: A comparison between KwaZulu and Swaziland. Human Ecology 18 (2): 203-209

[15] Hunter Jr ML, Hitchcock RK, Wyckoff-Baird B [1990] Women and wildlife in the southern Africa. Conservation Biology 4(4): 448-451

[16] Showers KB, Malahleha GM (1992) Historical environmental impact assessment: A tool of for analysis of past interventions in landscapes. Working Paper No. 8. The Project of 
Agriculture of the Joint Committee on African Studies, ISAS: National University of Lesotho.

[17] Rydgren B (1993) Environmental impacts of soil erosion and soil conservation. A Lesotho case study. PhD Thesis, UNGI Report No 85. Upsalla: Uppsala University.

[18] Dahlberg AC (1996). Interpretation of environmental change and diversity: A study from North-eastern Botswana. Dissertation Series No. 7. Department of Physical Geography, Stockholm University: Stockholm.

[19] Nsiah-Gyabaah K (1994) Environmental degradation and desertification in Ghana. A study of the Upper West Region. Aldershol \& Brookfield: Avebury Studies in Green Research..

[20] Herberlein TA (1972) The land ethic realised: Some social psychological explanation for changing environmental attitudes. Journal of Social Issues 28: 78-82

[21] Pitt MW, Yapp TP (1992) Perceptions of land degradation and awareness of conservation programmes in North-eastern New South Wales. In: Haskins PG, Murphy BM. Editors. People protecting their land, Proceedings of the 7th ISCO conference: Sydney. pp. 115-124

[22] Critchley W (1991) Looking after our land. Soil and water conservation in dryland Africa. Oxfam.

[23] Toulmin C, Chambers R (1990) Farmer-First: Achieving sustainable dryland development in Africa. IIED Paper No. 19. London: IIED.

[24] Bewket W, Teferi E (2009) Assessment of soil erosion hazard and prioritization for treatment at the watershed level: Case study in the Chemoga Watershed, Blue Nile Basin, Ethiopia. Land Degradation \& Development 20: 609-622, DOI: 10.1002/ldr.944

[25] Kangalawe RYM (2009) Land use /cover changes and their implications on rural livelihoods in the degraded environments of central Tanzania. African Journal of Ecology 47 (Suppl. 1): 135-141

[26] Ngana JO (1990). Modelling for periodic features in seasonal rainfall and its implications to water resources and agricultural planning. Research Report No. 27. Dar es Salaam: Institute of Resource Assessment, University of Dar es Salaam.

[27] Christiansson C (1981) Soil erosion and sedimentation in semi-arid Tanzania. Studies on environmental changes and ecological imbalance. Uppsala: Scandinavian Institute of African Studies.

[28] Eriksson MG (1999) Influence of crustal movements on landforms, erosion and sediment deposition in the Irangi Hills, central Tanzania. In: Smith BJ, Whalley WB, Warke PA. Editors. Uplift, erosion and stability: Perspectives on long-term landscape development. London: Geological Society of London, pp.157-168

[29] Kangalawe RYM (1995) Fighting soil degradation in the Kondoa eroded Area, Kondoa District, Tanzania: Socio-economic attributes, farmer perceptions and nutrient balance assessment. M.Sc. Thesis. Aas: Agricultural University of Norway. 
[30] Mbegu AC, Mlenge WC (1983) Ten Years of HADO. Dar es Salaam: Forest Division, Ministry of Natural Resources and Tourism.

[31] Clarke R (1986) The handbook of ecological monitoring. Oxford: Clarendon Press. $298 \mathrm{p}$

[32] Boyd HK, Westfall R, Stasch F (1981). Marketing Research: Tests and Cases. Illinois: Richard D. Inc.

[33] Hodgson JM (1985) Soil survey field handbook: Describing and sampling soil profiles. Technical Monograph No. 5. Harpenden Herts: Soil Survey, Rothamsted Experimental Station. 99 pp

[34] Johnson RA, Bhattacharyya GK (1992). Statistics: Principles and methods. Second edition. John Wiley \& Sons, Inc.

[35] Ryan BF, Joiner BL, Ryan Jr TA (1992) Minitab Handbook. Second edition. : Belmont California: Duxhury Press.

[36] Tosi JA, Hartshorn GS, Quesada CA (1982) HADO Project Development Study and Status of the Catchment Forestry. A Report to the Ministry of Natural Resources and Tourism, Tanzania. San Jones: Tropical Science Centre.

[37] Smith JL, Elliott LF (1990). Tillage and residue management effects on soil organic matter dynamics in semi-arid regions. Advances in Soil Science 13: 69-88

[38] Mohamed SA (1996) Farming systems and land tenure in Haubi Village of the Kondoa Eroded area. In: Christiansson C, Kikula IS. Editors. Changing environments: Research on Man-Land Interrelations in Semi-Arid Tanzania. Report No. 13. Nairobi; RSCU/SIDA. pp.77-83

[39] Mowo JG, Floor J, Kaihura FBS, Magoggo JP (1993) Review of fertiliser recommendations in Tanzania. Part 2 - Revised fertiliser recommendations for Tanzania. Soil fertility report No. F6. ARI Mlingano-Tanga: National Soil Service.

[40] Dejene A, Shishira EK, Yanda PZ, Johnsen FH (1997) Land degradation in Tanzania: Perceptions from the village. World Bank Technical Paper NO. 370. Washington DC: World Bank.

[41] Kikula IS (1989) Possible implications of the similarities and differences in perception of land degradation between planners and the planned. Research Paper No. 19. Dar es Salaam: Institute of Resource Assessment, University of Dar es Salaam.

[42] Kangalawe, RYM, Liwenga, ET, Majule, AE (2007) The Dynamics of Poverty Alleviation Strategies in the Changing Environments of the Semiarid Areas of Sukumaland, Tanzania. Research Report submitted to REPOA, Dar es Salaam.

[43] Kangalawe RYM, Lyimo JG (2009). Climate Change and Rural Livelihoods in Semiarid Tanzania. Proceedings of the $10^{\text {th }}$ WaterNet/WARFSA/GWP-SA Symposium: "Integrated Water Resources Management within the context of Environmental Sustainability, Climate Change and Livelihoods". Entebbe: 28 - 30 October 2009. 
[44] Kangalawe RYM., Majule AE, Shishira EK (2005) Land-use dynamics and land degradation in Iramba District, central Tanzania. Addis Ababa: Organisation for Social Science Research in Eastern and Southern Africa.

[45] Madulu NF, Mbonile MJ, Kiwia HDY (1993) Environmental impacts of migration in rural Tanzania. In: Population, Environment and Development. New York: United Nations, pp.73-91

[46] Cummingham OR, Jenkins QAL (1982) Natural disasters and farmers: A neglected area of research by rural sociologists. The Rural Sociologist 2(5): 325-330

[47] Nyega N (2008) Assessment of the beach management units strategy on the Lake Victoria fisheries resources in Ilemela District, Tanzania. MSc Dissertation, University of Dar es Salaam.

[48] Shadrack S (2009). Effectiveness of community based forest management approach in transforming local use of forest resources in Rufiji District. MSc Dissertation, University of Dar es Salaam.

[49] Mlenge W (2004) Ngitili: An indigenous natural resources management system in Shinyanga. Nairobi: Arid Lands Information Network - East Africa.

[50] Mung'ong'o CG (1995) Social processes and ecology in the Kondoa Irangi Hills, Central Tanzania. Meddelanden Series B 93. Stockholm: Department of Human Geography, Stockholm University.

[51] Östberg W (1995) Land is Coming Up: The Burunge of Central Tanzania and their environments. Stockholm Studies in Social Anthropology, 34. Stockholm: Department of Social Anthropology, Stockholm University.

[52] Mung'ong'o CG, Kikula IS, Mwalyosi RBB (2004). Geophysical and socio-political dynamics of environmental conservation in Kondoa District. Dar es Salaam: Dar es Salaam University Press.

[53] Kauzeni AS, Kikula IS, Shishira EK (1987) Developments in Soil Conservation in Tanzania. In History of Soil Conservation in the SADCC region. Research Report No. 8. SADCC Soil and Water Conservation and Land Utilisation Programme, Co-ordinating Unit: Maseru.

[54] Berry L, Townshend J (1973) Soil Erosion Conservation Policies in the Semi-Arid regions of Tanzania, A Historical Perspective. In: Rapp A, Berry L, Temple P. Editors. Studies on Soil Erosion and Sedimentation in Tanzania, BRALUP Research Monograph No. 1. BRALUP: Dar es Salaam; 241-253.

[55] Liwenga ET, Kangalawe RYM, Masao, CA (2007) The Implications of Agricultural Commercialization on Agro-diversity Management and Food Security in the Drylands of Central Tanzania. Research Report submitted to the Research Programme on Sustainable Use of Dryland Biodiversity (RPSUD), University of Dar es Salaam.

[56] Scoones, I. (1998). Sustainable rural livelihoods: A framework for analysis. IDS Working Paper No. 72. 
[57] Ellis, F. (1998). Household strategies and rural livelihood diversification. Journal of Development Studies 35 (1): 1-38. 